\title{
'We will nothing pay for wearing our own noses': Cosmopolitanism and Insularity in Cymbeline
}

\section{Robert Smallwood}

\section{(2) OpenEdition}

12 Journals

Electronic version

URL: http://journals.openedition.org/shakespeare/1273

DOI: $10.4000 /$ shakespeare. 1273

ISSN: 2271-6424

\section{Publisher}

Société Française Shakespeare

Printed version

Date of publication: 1 November 1994

Number of pages: 97-113

\section{Electronic reference}

Robert Smallwood, «'We will nothing pay for wearing our own noses': Cosmopolitanism and Insularity in Cymbeline ", Actes des congrès de la Société française Shakespeare [Online], $12 \mid$ 1994, Online since 01 January 2007, connection on 30 April 2019. URL : http://journals.openedition.org/shakespeare/1273 ; DOI : 10.4000/shakespeare.1273 
COSMOPOLITISME ET INSULARITÉ 


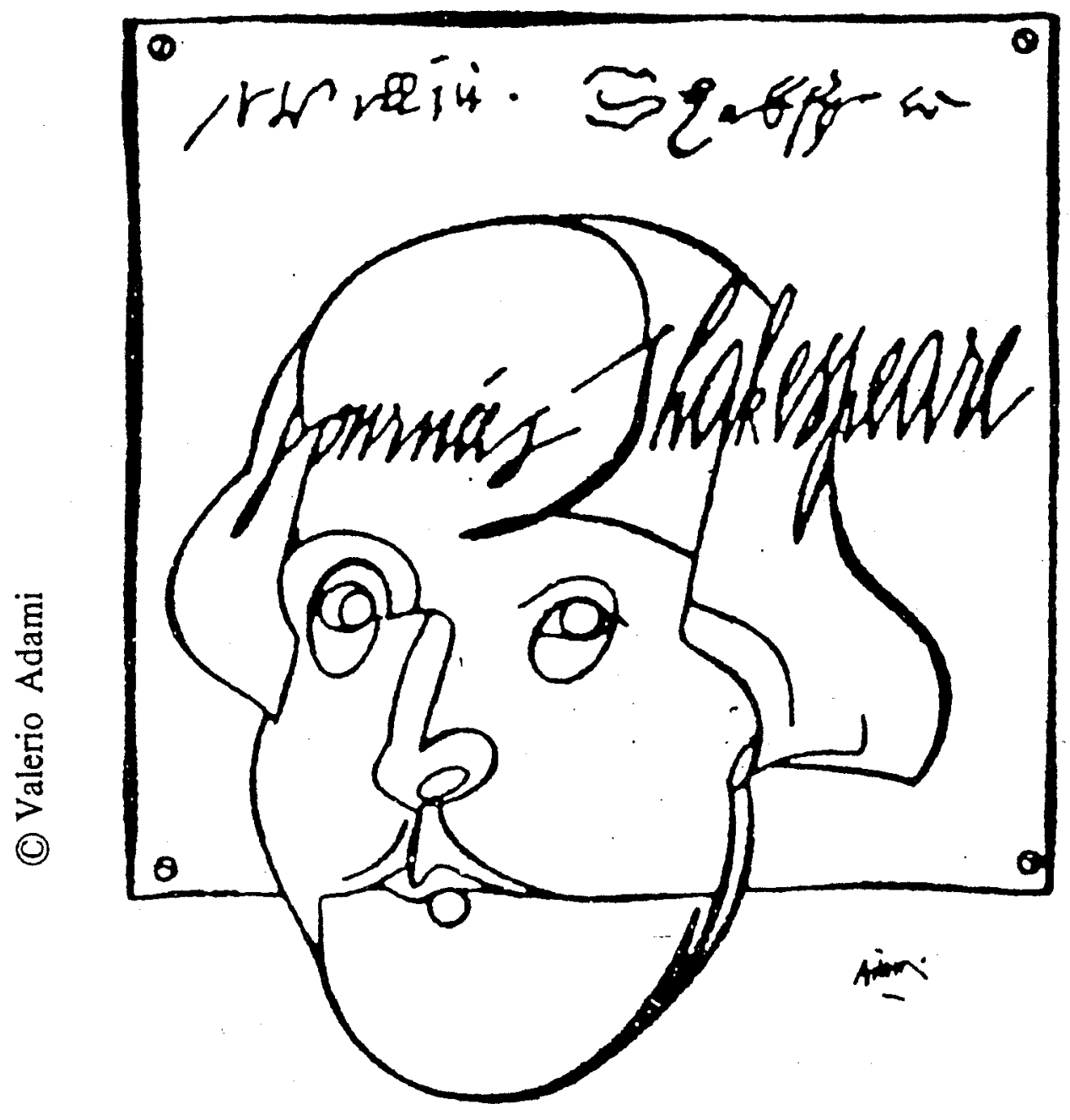

Affiche de Valerio Adami, spécialement conçue pour les journées Shakespeare 1979 


\section{SHAKESPEARE}

COSMOPOLITISME ET INSULARITÉ

Société Française Shakespeare

Actes du Congrès 1993

sous la direction

de

M. T. JONES-DAVIES

Ouvrage publié avec le soutien de

BARCLAYS

BARCLAYS BANK S.A

PARIS

LES BELLES LETTRES

1994 
Tous droits de traduction, de reproduction et d'adaptation réservés pour tous les pays.

(C) 1994 Société d'édition Les Belles Lettres, 95 bd Raspail 75006 Paris

ISBN 2.251.69122-7 


\section{"We Will Nothing Pay for Wearing Our Own Noses": Cosmopolitanism and Insularity in Cymbeline}

I want to begin in Innogen's bedchamber. «The crickets sing, and man's o'erlaboured sense / Repairs itself by rest» (II.ii.11-12) ${ }^{1}$. Iachimo, having just got out of his trunk (something which, as Granville Barker said long ago, no «tragically-potent scoundrel» would ever do $^{2}$ - though the degree of threat, of course, may be partly governed by the speed with which he opened the lid of the trunk), begins his assessment of the furniture of the room, committing it to memory for later recall in a wealth of detail quite different from the vagueness of his description in the scene itself. Having checked the design even of the andirons (was the play really written in exactly the same year as Sir Epicure Mammon was showing equal fascination with the same humble domestic utensil - 1610, 'The Year of the Andiron'), he turns his attention to the room's human contents.

Much of value and interest has been written about this scene over the years, and there is a whole long chapter on its iconography in Peggy Simonds's new book on the play ${ }^{3}$. The disturbing overtones of sexual threat in the scene, its voyeurism, the crude brutality of Iachimo's leering at the details of Innogen's body, these have all been largely discussed. The next couple of lines of Iachimo's speech make the point clearly:

Our Tarquin thus

Did softly press the rushes ere he waken'd

The chastity he wounded.

Tarquin we know all about, but it may be worth drawing attention to our - 'Our Tarquin'. Iachimo allies himself with his fellow countryman, as well as suggesting his own potential for becoming a fellow ravisher. Later in the play the island of Britain will be invaded, with the threat of violation, by Iachimo and his fellow countrymen landing at Milford Haven at the mouth of the most obvious sea route for penetration to the centre of the land. And 
here, in a sense, he plays the vanguard to that invasion, violating the secret haven, the inner sanctum of the nation, the bedroom of its Princess and heir apparent, and threatening further penetration. (A few minutes later, in playing time, Cloten's scene with the musicians will be strewn with bawdy quibbling. directed at Innogen, on fingering and penetration.) The sleeping Princess in her bed, trusting and guileless, finds her private space secretly invaded. «In a great pool, a swan's nest» (III.iv.140), the curious image which she uses later and to which I wish to return, is perhaps relevant here as the swan's whiteness is in danger of sullying, its nest threatened with violation. Innogen's bed is the ultimate insularity : the bed in the private chamber, in the private apartments, in the royal castle, in the middle of the island kingdom; and to the centre of this quintessential insularity reaches (penetrates) the quintessential cosmopolitanism of Iachimo, first encountered in circumstances of ostentatious internationalism in that most international of cities, Rome. The play's concern with the opposites of insularity and cosmopolitanism is distilled in this scene. «Though this a heavenly angel, hell is here» says Iachimo (1.50) as he gets back into his trunk, though I suspect that those apparently even more extreme opposites conceal a pun on hell as the space beneath the Jacobean stage, for the trunk is over the trap door : he doesn't really have to sit in it until the act break.

British insularity versus 'The Rest' : a venerable theme, and one to which Elizabethan writers and dramatists, Shakespeare among them, had frequent recourse - and it is still as present as ever, as the all-night sittings in the House of Commons on the Maastricht Treaty made amply clear ${ }^{4}$. Among many notable articulations of it in Cymbeline there is space here to consider two, each from a different point of view. One provides the title for this paper and comes from the Queen's son, whom she hopes will inherit the kingdom; the other from the King's daughter, who seems destined to inherit the kingdom. (In the end, of course, a quite different heir emerges.) One utterance is provoked by the arrival of foreigners in Britain, the other by the prospect of leaving Britain and living among foreigners. «There be many Caesars ere such another Julius», says Prince Cloten (III.i.12-13), when the Roman embassy arrives : «Britain's a world by itself, and we will nothing pay for wearing our own noses» (11.13-14). (Whether 'noses' means just noses, or implies another protuberant organ 
does not really affect the subtlety - or otherwise - of the political philosophy at work here.) This is pithy demagogic stuff, the sort of thing on offer in some of the in fact rather pathetically attended anti-Maastricht rallies during the passage of the Maastricht Bill through the British parliament. «Why should we pay tribute», Cloten goes on (1.43), and Mrs Thatcher, handbag at the ready, trudging off to Brussels to negotiate the great British rebate, wafts horribly into one's memory : why should the British pay tribute? "If Caesar can hide the sun from us with a blanket, or put the moon in his pocket, we will pay him tribute for light» (ll. 43-45). He is supported by his mother the Queen, a sharper political brain, directing her arguments at a slightly different section of the electorate :

Remember, sir, my liege, The kings your ancestors, together with The natural bravery of your isle, which stands As Neptune's park, ribb'd and pal'd in With rocks unscalable and roaring waters, With sands that will not bear your enemies' boats, But suck them to th' topmast.

The anti-Maastricht arguments presented by the anti-European right of the Conservative Party - by William Cash and Teddy Taylor and the rest of them - operate on exactly the same vacuous emotional level : Cloten-Cash, Teddy-the-Queen-Taylor - plus ça change, plus c'est la même chose. What is remarkable about the Queen's speech is the closeness of the echo of earlier Shakespearian paeans to British insularity, one of them, at least, from a seemingly more respectable political pedigree :

This precious stone set in the silver sea

Which serves it in the office of a wall ...

England, bound in with the triumphant sea,

Whose rocky shore beats back the envious siege

Of wat'ry Neptune ...

(Richard II, II.i.46-47, 61-63)

That is John of Gaunt, of course. In King John, the Duke of Austria had offered what is presumably Shakespeare's earliest articulation of the idea : 
... that pale, that white-fac'd shore,

Whose foot spums back the ocean's roaring tides

And coops from other lands her islanders.

... England, hedg'd in with the main,

That water-walled bulwark, still secure

And confident from foreign purposes ...

It is as though in Cymbeline Shakespeare is returning to re-examine earlier political themes - and Austria's description, two lines later, of England as «that utmost corner of the west» will reappear in identical form in the final scene of Cymbeline - but to re-examine them from different perspectives and with different consequences. The reappearance of John of Gaunt's patriotic hymn to insularity in the mouth of that cat-and-dog-poisoner of a wicked stepmother, the Queen in Cymbeline, is a most arresting phenomenon. The whole idea of the protectiveness of insularity reaches gloriously bathetic absurdity as Cloten (Bill-Cloten-Cash), would-be arbiter of the national destiny, flings his final patriotic utterance at the Roman envoys : «if you seek us afterwards ... you shall find us in our salt-water girdle» (11.80-82) : with exquisite irony he has forgotten being infuriated a few scenes earlier by a metaphorical comparison of himself to his rival Posthumus's «meanest garment» (II.iii.134 ff).

Three scenes after Cloten's confrontation with the Roman embassy comes our second example, as Innogen is faced with the necessity for exile from Britain. «If not at court,/ Then not in Britain must you bide», says Pisanio, and her reply has a strange power :

Where, then?

Hath Britain all the sun that shines ? Day? Night?

Are they not, but in Britain? I'th' world's volume

Our Britain seems as of it, but not in't :

In a great pool, a swan's nest : prithee think

There's livers out of Britain.

(III.iv.135-141)

The King's daughter's statement is in interesting contrast to that of the Queen's son and, given our theme of insularity and cosmopolitanism, has clearly moved a long way across the spectrum towards the cosmopolitan. «Britain is a world by itself», Cloten had said ; Innogen tries, from the limited perspective of her youth and the 
isolation - the insularity - of her experience, to see Britain in an international, a cosmopolitan, context: «I' the' world's volume ... Britain seems as of it, but not in't». And then the curious image : «In a great pool, a swan's nest». It is a beautiful, an elegant image - but quite what it means is not, I think, easy to determine. In one sense, one might see it as a reworking of Cloten's idea: the swan's nest as the isolated enclave, the 'world by itself', indifferent to the general existence of the rest of the world, the pool ; and that pool may perhaps be thought of as unclean. But to dwell on the idea for a moment soon weakens that interpretation. Britain, she says, is of the world, though not in it, as the nest of the swan, raised above the water level, is nevertheless part of the life of the pool, perhaps even its dominant part. Geography may have separated Britain from the rest of Europe, but it is still, as she says, 'of it', still inextricably dependent upon it as is the swan upon the pool from which it draws its means of life. Might we even go so far as to see the swan's nest as giving life to the pool, being the heart of it - an idea again to be heard in the European political debate in Britain, with the pro-Maastricht lobby fond of repeating the cliche that they wish to see Britain 'at the heart of Europe'.

In the scene of the confrontation of the Roman envoys and the British court both sides offer a brief history lesson. Caius Lucius, the Roman ambassador, is first :

When Julius Caesar ... was in this Britain And conquered it, Cassibelan, thine uncle ... ... for him

And his succession, granted Rome a tribute, Yearly three thousand pounds ; which (by thee) lately Is left untended.

(III.i.1-9)

And after the aggressive interlude of Cloten's and the Queen's defiance, Cymbeline comes back, courteously but determinedly, to the history lesson :

Our ancestor was that Mulmutius which Ordain' d our laws, whose use the sword of Caesar Hath too much mangled ; whose repair, and franchise, Shall (by the power we hold) be our good deed. 
The appeal to history to justify entrenched political positions is a proceeding of venerable pedigree, obviously; how impressive we are meant to find Mulmutius Dunwallow, one of the more distant of Geoffrey of Monmouth's Kings of Britain, as a counterweight to the name, and firm historicity, of Julius Caesar, I am not sure. But by the end of the conference between Cymbeline and his court on one side, and the Roman envoys on the other, the ideal of national independence and separateness is in the ascendancy: the Clotens and the Cashes, the Taylors and the Queens, have created the division they seek. When the sides meet again a few scenes later for Lucius's departure, Cymbeline takes shelter behind the idea of the 'will of the people' :

Our subjects, sir,

Will not endure his [Caesar's] yoke; and for ourself

To show less sovereignty than they, must needs

Appear unkinglike.

(III.v.4-7)

A referendum, we heard throughout the Maastricht debate, would decide the issue; the British would reject integration within Europe : "We will nothing pay for wearing our own noses». The Queen's son is running the show; the swan is staying out of the pool ; the treaty with Rome is off.

Just as the Queen's son's position on wearing our own noses is restated shortly afterwards, so too the King's daughter's little speech of analysis of Britain's relationship with the rest of the world is also developed in a remark a few moments later. Pisanio, imagining the Princess to be now overseas, utters a little prayer : «Safe mayst thou wander, safe return again» (III.v.106). It is, of course, at one fundamental level, the most perfect encapsulation of the whole idea of romance that one could wish to find, but it is not irrelevant also to the play's internationalism, its powerful sense of homeness and awayness and of the possibility of their being safely interchangeable rather than mutually incompatible : in the best of worlds, wandering may be as safe as returning.

Posthumus is the play's principal wanderer, and his exile takes him at once to an away fixture of flamboyant internationalism. «Enter... Iachimo [an Italian], a Frenchman, a Dutchman and 
a Spaniard» says the stage direction to Act I, Scene v. Two of these never speak and are clearly relics from the source, but their survival is a clear demonstration of the area in which the dramatist's mind was here working: the homespun Briton, guileless, honest, and a bit naive, among the continental sophisticates, the city slickers ${ }^{5}$. There's a sense of the urban - of urbane-ness, and of urbanity - about the Roman scenes of this play, quite unlike the entirely non-urban (and frequently savage) settings of the British scenes : we may hear about marching 'towards' Lud's Town, but we never seem actually to be there. Into this elegant Roman world, this blasé, cynical society, comes the idealistic Posthumus, quick to take offence, standing on principles, making an issue of what his interlocutors would suavely shrug off; and when Iachimo comes back with the alleged evidence of Innogen's guilt, he rushes to conclusions, revealing the rawness of his feelings, blurting things out, and generally behaving in a thoroughly embarrassing way. Left alone to face the consequences of being duped, that tendency to blurt things out takes his language off into a lurching and destructive savagery:

Perchance he spoke not, but

Like a full-acorn'd boar, a German one,

Cried "O !" and mounted ...

$$
\text { (Il.iv.167-169) }
$$

The arrival of yet another European national ('a German one') to add to the French, Dutch, Spaniards, and Italians is fascinating. They are clearly lining up against the lonely and vulnerable Brit, these cunning continental seducers, threatening his masculinity through cuckoldry, trying to take over his wife, his possessions (through the demand for tribute), and, in the invasion, his island.

While Posthumus in this Renaissance version of the Strasbourg parliament looks rather a country bumpkin, Iachimo at the British court seems very much the sophisticated cosmopolitan operator amongst the provincials. Innogen expresses the idea of the corrupt intruder very powerfully in her response to his sexual suggestions :

The king my father shall be made acquainted

Of thy assault : if he shall think it fit

A saucy stranger in his court to mart 
As in a Romish stew, and to expound

His beastly mind to his, he hath a court

He little cares for.

This motif of sophisticated foreign (usually Italian) falsity versus British purity and simplicity is recurrent through the play :

What false Italian

(As poisonous tongu'd as handed) hath prevail'd

On thy [Posthumus's] too ready hearing?

(III.ii.4-6)

asks Pisanio; «drug-damn'd Italy hath outcraftied him» says Innogen (III. iv.I5) ; and Iachimo himself, confessing his crimes at the end of the play, sees them in exactly the same terms of foreign cunning versus native simplicity :

Being thus quench'd

Of hope, not longing, mine Italian brain

Gan in your duller Britain operate

Most vilely.

(V.v.195-198)

All these currents come most vividly together in the moment with which I began, as the Italian invader menaces the innocently sleeping figure of the British princess.

«To remark ... the confusion of the names and manners of different times ... were to waste criticism upon unresisting imbecility» wrote Dr Johnson, in a famous attack on Cymbeline ${ }^{6}$. That 'confusion', of course, is vital in permitting the double standard of the play's examination of anglo-continental relations. Against the Europeanness represented by Iachimo the insular hackles may perhaps almost legitimately rise; in response to the brainless vulgarity of Cloten's abuse of the Europeanness of Caius Lucius, on the other hand, the play seems to invite a sense of national shame. The division the play creates between 'Romans' and 'Italians' governs its presentation of ideas of cosmopolitanism and insularity. There is never the slightest possibility of our sharing Cloten's crude hostility to Rome, even though Rome is here invader of the homeland. The complexity of the response may derive from Holinshed : 
Whether this controversie which appeareth to fall forth betwixt the Britains and Augustus, was occasioned by Kymbeline, or some other prince of the Britains, I have not to avouch : for that by our writers it is reported that Kymbeline, being brought up in Rome, and knighted in the court of Augustus, ever shewed himselfe a friend to the Romans, and chieflie was loth to breake with them, because the youth of the Britaine nation should not be deprived of the benefit to be trained and brought up among the Romans, whereby they might learne both to behave themselves like civill men, and to atteine to the knowledge of feates of warre ${ }^{7}$.

But it hardly needs an English chronicler of very modest literary distinction to instruct Shakespeare in a sense of indebtedness to the civilizing influence of Rome. The pervasiveness of this idea in Renaissance literature in general, and Shakespeare's own recent career as a dramatist of Roman history in particular, would do that much more amply. The Holinshed passage is interesting, however, in presenting the chronicler's confusion about who was and who was not fighting the Romans, for this seems to me something that Shakespeare has deliberately transplanted into his play. Are we entirely certain which side Posthumus's father and brothers were fighting on when they lost their lives? His father

did join his honour

Against the Romans with Cassibelan,

But had his titles by Tenantius, whom

He served with glory and admired success.

A few scenes later, on the other hand, Philario, a Roman, tells us (speaking of Posthumus) «His father and I were soldiers together to whom I have been often bound for no less than my life» (I.v.26-27). At the other end of the play Posthumus finds himself brought hither

Amongst th' Italian gentry, and to fight

Against my lady's kingdom.

In disguise he in fact fights with the Britons but is then taken prisoner as a Roman. Belarius is supposed, years before the play begins, to have been 'confederate with the Romans' (III.iii.68). He denies it, and we are presumably supposed to believe him, but the 
general sense of fluidity about Romano-British loyalties is part of the play's deliberately created mood. Certainly the first mention of Romans entering Britain in the play - the news of the arrival of the embassy of Caius Lucius - hardly presents them as enemies:

Caius Lucius ... A worthy fellow, Albeit he comes on angry purpose now;

But that's no fault of his: we must receive him According to the honour of his sender, And towards himself, his goodness forespent on us, We must extend our notice.

Cymbeline's response is as cosmopolitan as those of his Queen and stepson, when they later confront Lucius, are insular. It is a cosmopolitanism reinforced later in that scene when, after war has been formally declared, Cymbeline reveals more of his own Roman education :

Thou art welcome, Caius.

Thy Caesar knighted me ; my youth I spent

Much under him ; of him I gather'd honour,

Which he to seek of me again, perforce,

Behoves me keep at utterance.

(III.i.70-74)

We are left deeply confused, it seems to me, about which side we are supposed to be on in this quarrel and convinced that the disintegration of the alliance is deplorable; we are thus inevitably suspicious, if not contemptuous, of the insular patriotism of the British war party. A long time before battle commences, we are also informed by the Soothsayer that the Romans are going to win. He describes his vision :

I saw Jove's bird, the Roman eagle, wing'd

From the spongy south to this part of the west,

There vanish'd in the sunbeams, which portends

(Unless my sins abuse my divination)

Success to th' Roman host.

(IV.ii.348-52)

He may (as the old man and the boys, and the narrow lane, will later prove) be wrong militarily, but politically he is right: the play ends with the Romans getting exactly what they came for, a peace 
settlement, and the former level of tribute. The play never, in fact, invites us to anticipate or to hope for a victory of British insularity over Roman internationalism.

I have remarked already on the geographical vagueness of the British court scenes of Cymbeline. The energetic route-plotting and castle-identifying of Shakespeare's earlier plays about a later period of English history are here entirely absent. Presumably we are to imagine a location (if our mental and emotional constitution makes it necessary for us to imagine locations for scenes in truth set on stages) in what we now call England - i.e. east of the River Severn, since in the scene of Lucius's departure Cymbeline orders that he be accompanied by an escort «Till he have cross ' $d$ the Severn» (III.v.17). (Why he's returning to Gaul via the extremest west of Wales is too abstruse a bit of geography to embark on here.) But if all these court scenes are supposed to be in 'Lud's Town' this is never clearly apparent and any indication of what that metropolis might be like is altogether wanting - in obviously very striking contrast to the firm location in Rome of all the scenes outside Britain. The geographical portion of the British island that is insisted on, of course, is Wales - not, as Bernard Shaw said in his outrageously funny review of the Irving production in 1896, some «charming spot near the valley of the Wye ... on a nice Bank-holiday afternoon» but «in the gloom amid the wolf and robber-haunted mountain gorges which formed the Welsh mountains of Shakespeare's imagination in the days before the Great Western ${ }^{8}$. And there in Wales is quintessential Britishness, ultimate insularity. The exiled princes even reveal their princeliness in their discontent with it :

We poor unfledg'd

Have never wing'd from view o' th' nest ; nor know not

What air's from home.

(III. iii.27-29)

Their life they see as «a cell of ignorance» (1.33) and conclude, simply, impressively: «We have seen nothing : / We are beastly» (11. 39-40). The play charts the journey from this insular beastliness to international civilization, a journey that begins with the Roman invasion :

So please your majesty,

The Roman legions, all from Gallia drawn,

Are landed on your coast, with a supply

Of Roman gentlemen, by the Senate sent.

(IV. iii. 23-27) 
The British leader prepares to meet the threat :

Good my liege,

Your preparation can affront no less

Than what you hear of. Come more, for more you' re ready.

And Cymbeline replies :

I thank you : let's withdraw And meet the time, as it seeks us. We fear not What can from Italy annoy us.

It is a situation that Shakespeare had treated in several earlier plays, this threat to the homeland, this violation of the island sanctuary. In all of them the political morality of the situation is confused and ambiguous, as it is here, with powerful arguments in favour of the invader alongside considerable emotional sympathy attaching to the defender. In King John, the Dauphin invades England following the death of the child Arthur, for which John is morally blameworthy even if not legally responsible. But the language of the defender - in this case the Bastard Faulconbridge - deals in nothing but the nationalistic absolutes :

This apish and unmannerly approach,

This harness ' $d$ masque and unadvised revel,

This unhair'd sauciness and boyish troops,

The king doth smile at ...

And like an eagle o'er his aery towers,

To souse annoyance that comes near his nest.

(V.ii.131-150)

The language is not dissimilar as Richard III faces an invader entering his kingdom, like those who threaten Cymbeline, through Milford Haven :

Remember whom you are to cope withal :

A sort of vagabonds, rascals, and runaways ;

A scum of Bretons and base lackey peasants ...

Let's whip these stragglers o'er the seas again,

Lash hence these overweening rags of France.

(V.iii.316-329)

Both of them are on extremely shaky ground, politically, morally, and militarily, as they rally the forces of island defence, but that 
makes little difference to the rhetoric: Nor does similar precariousness at first affect the Duke of York in Richard II as he faces Bolingbroke - also with an army recruited in France :

Why have those banish'd and forbidden legs

Dar'd once to touch a dust of England's ground? ... why have they dar'd to march

So many miles upon her peaceful bosom, Frighting her pale-fac'd villages with war And ostentation of despised arms?

(II. iii.89-94)

In all these plays there is sympathy (sometimes more, sometimes less) with the invader and a sense of the harnessing of the standard 'repel boarders' clichés in opposing him. The clichés hardly break surface in King Lear as the current British political establishment - Albany and Edmund, Goneril and Regan - set aside their differences to defeat Cordelia and her father and her invading French army.

The general question, whose side would an Elizabethan dramatist expect his audience to take if he wrote a play showing a foreign army invading Britain, would seem at first glance to be capable of only one likely answer; yet these Shakespearian examples are far from straightforward in the responses they suggest, and in Shakespeare's final exploration of the idea here in Cymbeline the situation is equally ambiguous. The rhetoric of defiance remains, as we have seen, but the instigators of the confrontation (Cloten and the Queen) have disappeared from the scene when the invasion actually occurs, and the rhetoric has something of a hollow ring : «We fear not / What can from Italy annoy us». That is Cymbeline's public statement, but less overtly he admits that «We grieve at chances here» (IV.iii.35). In their Welsh retreat the King's unknown sons decide to fight against the invader, but their reasons are largely negative. If they do not

the Romans

Must or for Britons slay us or receive us

For barbarous and unnatural revolts

During their use, and slay us after.

(IV.iv.4-7) 
Only the British weather seems unequivocally confident about which side to be on, as Iachimo discovers :

I have belied a lady,

The princess of this country; and the air on't

Revengingly enfeebles me.

(V.ii.2-4)

Another mediterranean victim of the British climate!

Cymbeline is probably the earliest of four surviving early seventeenth-century plays about the Roman invasions of Britain - Fletcher's Bonduca, The Valiant Welshman by 'R.A.', and Jasper Fisher's The True Trojans followed it. All of them seem to invite the same ambiguous response, with not infrequent disloyalties and defections, to their presentation of RomanoBritish conflict, and all of them end with Britain and Rome at peace. Only in Cymbeline, however, do the British conclude that peace from a position of victory and strength : in each of the other plays, peace, albeit a welcome and honourable peace, follows military defeat.

«My peace we will begin», says Cymbeline,

and Caius Lucius,

Although the victor, we submit to Caesar, And to the Roman empire ; promising

To pay our wonted tribute, from the which

We were dissuaded by our wicked queen.

(V.v.460-464)

Thus baldly stated it might sound like an absurd volte-face, but it is, surely, much more the appropriate and deeply satisfying culmination of a movement, a ground swell, which has governed the play throughout. The instinctive response to the civilizing goodness that the Roman Caius Lucius represents, voiced first by Cymbeline, is repeated by characters we trust implicitly, Pisanio and Innogen. The isolation of Britain was always an aberration: «let / A Roman and a British ensign wave / Friendly together» (V.v.480-482). Eleven years earlier, at the end of his long endeavours in staging the history of fifteenth-century England, Shakespeare chose, in Henry $V$, a moment for his exit from the dramatization of Anglo-French relations when the two nations are 
at peace, when «English may as French, French Englishmen, / Receive each other» (V.ii. 385-6). From the nationalism, the insularity, of the English histories, he had turned, it would seem within a very short time of completing Henry $V$, from Holinshed to Plutarch, the two greatest narrative influences on his dramatic story-telling, from a provincial English collector of other men's scholarship and opinions to one of the more considerable literary figures in the Graeco-Roman world, whose work reached him by way of translation into another European language. If ever one wanted a precise example of this journey from the insular to the cosmopolitan it might be that switch from Holinshed to Plutarch somewhere around the summer of 1599. And through Plutarch Shakespeare explores the evolution of Rome from primitive city state, through republic, to empire and to world domination, only leaving behind its history as Augustus feels that «The time of universal peace is near» (Antony and Cleopatra, IV.vi.5). Those twin strands of Shakespeare's career as historical dramatist, the British and the Roman, come together in Cymbeline as Wilson Knight long ago pointed out ${ }^{\prime}$, in a culmination in peace. . My peace we will begin»; and the British is resolved into the European, the insular into the cosmopolitan. The Queen is dead (it having been reported, unsurprisingly, if a little curtly, that before dying she had the decency to help resolve the plot by confessing that «she never lov'd» her husband and had, indeed, «abhorr'd [his] person» (V.v.37, 40)). Cloten is dead, too, his clotpoll having been sent down the Welsh mountain stream by a step-brother now rescued from insular beastliness and restored to a princeliness that even includes the rediscovery of a name resonant in its Latinity. And the treaty with Rome is back on : «My peace we will begin». Emrys Jones has persuasively linked the mood of the play's ending with James I's vision of himself as European peacemaker, Jacobus Pacificus, the new Augustus, a concept which had led, in the year of the play's probable first performance, to peace overtures even as far as Rome and the Vatican itself ${ }^{10}$. But the moment of British history which Shakespeare chose to dramatize, like the moment in which he dramatized it, are merely snapshots of a latent and constant tension in the British world-view between littleEnglanderdom and Europeanism, between the swan sulking in its nest or swimming in the pool, between cosmopolitisme et insularité. The convenience of timely dramatic deaths to silence the little Englanders, the Clotens and the Queens, may have been 
replaced by that more lingering and drawn-out form of demise on the national political stage, translation to the House of Lords, for the Thatchers and the Tebbits, but there are still plenty of Cashes and Taylors bobbing up to take their places. The treaty with Rome has been replaced by the Treaty of Rome, but Cymbeline's choice of verb in the play's penultimate sentence had an uncanny topicality during the long series of all-night sittings before the Maastricht Bill finally passed the House of Commons in July 1993 : «Our peace we'll ratify» (V.v.483).

Robert SMALLWOOD

The Shakespeare Centre, Stratford-upon-Avon

\section{NOTES}

1. There being no Cymbeline in either the Oxford or New Cambridge editions, I have used the new Arden Cymbeline edited by J. M. Nosworthy (London, 1955) ; for the sake of consistency, other Shakespeare plays are also quoted from new Arden editions. I have, however, accepted the new orthodoxy with regard to the spelling of the name Innogen.

2. Harley Granville Barker, Prefaces to Shakespeare, two-volume edition (London, 1958), I, 512.

3. Peggy Muñoz Simonds, Myth, Emblem, and Music in Shakespeare's 'Cymbeline' : An Iconographic Reconstruction (Newark, Delaware, 1992).

4. When this paper was delivered at the conference of the Société Française Shakespeare (and I am grateful to the Sociéte, and to Mme Jones-Davies, for their gracious invitation), in February 1993, the Maastricht Bill was in the earlier stages of its turbulent passage through the British House of Commons and beginning the increasingly depressing process of exposing the more repellently insular attitudes on the right wing of the Conservative Party. It finally completed its progress in July 1993 - ironically, in the same week as the international currency speculators' assault on the European Exchange Rate Mechanism pushed the dream of greater European unity further out of reach.

Paris.

5. My own position precisely, of course, as I read this paper in

6. Johnson on Shakespeare, edited by W. K. Wimsatt, Penguin Shakespeare Library (Harmondsworth, 1969), p. 136. 
7. Raphael Holinshed, The Chronicles of England, Scotland, and Ireland (1587), in Narrative and Dramatic Sources of Shakespeare, edited by Geoffrey Bullough, 8 vols (London, 1957-75), VIII, 44.

8. Shaw on Shakespeare, edited by Edwin Wilson (London, 1961), p. 56.

9. G. Wilson Knight, The Crown of Life (London, 1947 ; reprinted 1958), pp. 130-140.

10. Emrys Jones, 'Stuart Cymbeline', Essays in Criticism, 11 (1961), 84-99. 